\title{
The vaccinaTion \& Hpv Knowledge (THinK) questionnaire: a reliability and validity study on a sample of women living in Sicily (southern-Italy)
}

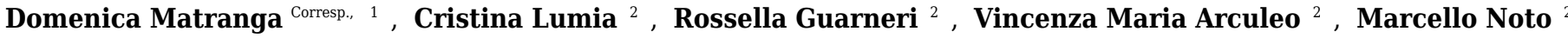 \\ , Alessia Pivetti ${ }^{2}$, Gregorio Serra ${ }^{2}$, Maria Francesca Guarneri ${ }^{2}$, Antonio Spera ${ }^{2}$ \\ 1 Department of Health Promotion and Mother and Child Care "G. D'Alessandro", University of Palermo, Palermo, Sicily, Italia \\ 2 Unit of Gynecology and Obstetrics, Azienda Ospedaliera Universitaria Policlinico “Paolo Giaccone”, Palermo, Sicily, Italia \\ Corresponding Author: Domenica Matranga \\ Email address: domenica.matranga@unipa.it
}

Objective. The aim of this study was to introduce the VaccinaTion \& Hpv Knowledge (THinK) questionnaire to assess knowledge about human papillomavirus (HPV) and attitude to HPV- vaccination. Its reliability and validity was demonstrated in a sample of women living in Sicily (Southern-Italy). Methods. A cross-sectional survey was conducted on a sample of 220 women at the "Paolo Giaccone" University Hospital in Palermo (Sicily), aged 18-61. Data were analyzed through Cronbach's alpha and exploratory factor analysis, followed by a structural equation model with measurement component. The two-level data structure was explicitly considered. Results. Three dimensions were found: "knowledge of HPV infection (kHPV), "Attitude to be vaccinated against HPV (aHPV)" and "Knowledge about vaccines (KV)" (97\% overall explained variance). Internal consistency was good for the whole questionnaire (0.82) and the first dimension (0.88) and acceptable for the second (0.78) and the third dimension (0.73). $23 \%$ of women showed no or little knowledge of HPV and $44.3 \%$ of women had no or little knowledge about HPV induced lesions. Discussion. The use of a validated questionnaire may serve as a useful measure to assess general knowledge about HPV and attitude towards vaccination against HPV in the primary prevention setting. 
Domenica Matranga ${ }^{1}$, Cristina Lumia ${ }^{2}$, Rossella Guarneri², Vincenza Maria Arculeo $^{2}$, Marcello Noto $^{2}$, Alessia Pivetti ${ }^{2}$, Gregorio Serra ${ }^{2}$, Maria Francesca Guarneri ${ }^{2}$, Antonio Spera ${ }^{2}$

${ }^{1}$ Department of Health Promotion and Mother and Child Care "G. D'Alessandro", University of Palermo, Palermo, Sicily, Italy

${ }^{2}$ Unit of Gynecology and Obstetrics, Azienda Ospedaliera Universitaria Policlinico "Paolo

Giaccone", Palermo, Sicily, Italy

Corresponding Author:

Domenica Matranga ${ }^{1}$

Via del Vespro, 133; 90127 Palermo, ITALY.

Email address: domenica.matranga@unipa.it

\section{ABSTRACT}

Objective. The aim of this study was to introduce the VaccinaTion \& Hpv Knowledge (THinK) questionnaire to assess knowledge about human papillomavirus (HPV) and attitude to HPVvaccination. Its reliability and validity was demonstrated in a sample of women living in Sicily (Southern-Italy).

Methods. A cross-sectional survey was conducted on a sample of 220 women at the "Paolo Giaccone" University Hospital in Palermo (Sicily), aged 18-61. Data were analyzed through Cronbach's alpha and exploratory factor analysis, followed by a structural equation model with measurement component. The two-level data structure was explicitly considered.

Results. Three dimensions were found: "knowledge of HPV infection (kHPV), "Attitude to be vaccinated against HPV (aHPV)" and "Knowledge about vaccines (KV)" (97\% overall explained variance). Internal consistency was good for the whole questionnaire (0.82) and the first dimension (0.88) and acceptable for the second (0.78) and the third dimension (0.73). 23\% of women showed no or little knowledge of HPV and $44.3 \%$ of women had no or little knowledge about HPV induced lesions.

Discussion. The use of a validated questionnaire may serve as a useful measure to assess general knowledge about HPV and attitude towards vaccination against HPV in the primary prevention setting. 
39

40

41

42

43

44

45

46

47

48

49

50

51

52

53

54

55

56

57

58

59

60

61

62

63

64

65

66

67

68

69

70

71

72

73

74

75

76

77

78

Human Papilloma Virus (HPV) infection is the most frequent among sexually transmitted diseases in the world. Cervical cancer is closely related to virus action, which is the main cause of cervical intraepithelial neoplasia and invasive lesions [1].

Three HPV vaccines are at the moment available in many countries throughout the world. The bivalent (Cervarix, GSK biologicals) HPV vaccine prevents infections with the high-risk (HR) HPV 16 and 18 . These genotypes are responsible for approximately $70 \%$ of cervical cancer cases globally and are considered responsible for a significant number of cervical low- and high- grade squamous intraepithelial lesions (LSIL and HSIL, respectively) [2]. The quadrivalent HPV vaccine (Gardasil, Sanofi Pasteur MSD), in addition to HR 16 and 18, also targets the LR HPV 6 and 11 that are associated with $90 \%$ of anogenital warts in men and women [3]. Both bivalent and tetravalent vaccines have been shown to be effective and immunogenically valid in trials conducted in recent years with efficacy tests up to 55 years, especially in those who are virusnaïve [4]. Finally, the enavalent HPV vaccine (Merk, Sanofi Pasteur MSD, 9vHPV, trade name Gardasi19), in addition to the four genotypes of the quadrivalent vaccine, also targets five additional HR genotypes, namely HPV 31/33/45/52/58, which are the most frequently detected types in invasive cervical cancer worldwide, after HPV 16 and HPV 18 [5]. Vaccination can be administered to people who did not have any contact with the genotypes that are covered; for this reason, it is preferable to get vaccinated in adolescence, before sexual activity begins and before any potential exposure to virus [6].

A cross-sectional study showed a prevalence of HR HPV infections of $24 \%$ in a group of young Sicilian women (18-24) [7]. According to the official statistics about the HPV vaccine coverage (year 2015), in Sicily the percentage of young women (fully) vaccinated against HPV is $44.10 \%$ compared to the national average rate of $62.15 \%$ [8]. In a female population living in Sicily, it has been shown that the switch to the enavalent vaccine would increase the prevention of cervical HSIL in up to $90 \%$ of cases [5].

Awareness of the risks associated to HPV infection is extremely important. In a large systematic review, Hendry et al [9] showed that misperception of risk could prevent from accepting vaccination; moreover, the correct knowledge of virus epidemiology can lead to adopt behaviors, as an example the use of condom, to minimize the risk of infection. Most of the surveys conducted until now about HPV awareness and attitude to specific vaccination have involved young people [10-11]. In 2008 an Italian Survey among women 14-24 showed the need to strengthen HPV knowledge, since only $23.3 \%$ of interviewed have heard about HPV and cervical cancer [12]. Knowledge about HPV infection has been shown to be poor among the public, students, patients and health professionals [13-14] and, more recently, among European adolescents [15]. Furthermore, according to other studies, vaccination in women over 25 years, together with a screening program, offers the opportunity to reduce the incidence of cervical cancer in countries with limited resources and high disease burden. In 2017, results from a large survey in Italy showed that $73,8 \%$ of interviewed people were conscious about availability of HPV vaccine, but no trust in vaccines and believe that PAP test is enough for prevention were expressed by $14,0 \%$ and $14,3 \%$ of women respectively [16]. 
79 The aim of this study was to assess knowledge of HPV and attitude to HPV-vaccination in a 80 sample of Sicilian adult women and to demonstrate reliability and validity of the questionnaire 81 used. The choice of an adult target population for this study relates to the importance of 82 disseminating the culture of vaccination, just increasing parental awareness and attitude. The 83 VaccinaTion \& Hpv Knowledge (THinK) questionnaire was developed to be used in the first 84 approach to the patient both in hospital and in outpatient service.

85

86

\section{MATERIALS \& METHODS}

\section{Participants}

A cross-sectional survey was conducted at the "Paolo Giaccone" University Hospital in Palermo (Sicily) from April to December 2017. The study included 220 women, aged 18-61, consecutively enrolled from the Unit of Gynecology and Obstetrics (Ob/Gyn) (136 women) and from the University ambulatory clinic (UAC) ( 84 women). The $\mathrm{Ob} / \mathrm{Gyn}$ is an outpatient service for women of all age groups while the UAC supplies free healthcare services to students and fresh graduates. Women apply to the $\mathrm{Ob} / \mathrm{Gyn}$ either as they complain about some acute or chronic disorders or as they ask for a complete gynecological check-up. Alternatively, women apply to the UAC in order to receive information on contraception, sexually transmitted diseases (STD) and/or gynecological screening visits. Women already vaccinated against HPV were excluded from the study.

\section{The vaccinaTion \& Hpv Knowledge (THinK) questionnaire}

Enrolled women were given advices about the aim of the study. This study was conducted according to the guidelines laid down in the Declaration of Helsinki and all procedures were approved by the Research Ethics Committee at "Paolo Giaccone" University Hospital (Reference number 8/09/2018). Verbal informed consent was obtained from all participants. The THinK questionnaire included 16 items (Figure 1), using a 5-level Likert scale (yes, much somewhat, little, no). Questions concerned general knowledge about vaccination (acceptance, administration, effectiveness), HPV and related risks and acceptability of vaccine. Age, birthplace and education of each respondent were requested too. The draft of the THinK questionnaire was reviewed by five experts within "Paolo Giaccone" University Hospital to check its completeness and its suitability to be used in the first approach to the patient both in hospital and in outpatient service. Recommendations for improvement were also sought.

\section{Statistical methods}

Descriptive statistics were calculated for participants' general characteristics.

As a first step, an exploratory factor analysis (EFA) was carried out to describe the joint variability of the dimensions of the THinK questionnaire. Factors were rotated using the varimax approach to ease interpretation. Internal consistency was assessed for each dimension using the Cronbach's alpha coefficient. Higher values indicate that scores on the considered dimension are 
119 internally consistent. Internal consistency is considered poor if the alpha value is below 0.60 , 120 questionable if between 0.60 and 0.70 , acceptable between 0.70 and 0.80 , good between 0.80 and 1210.90 and excellent if not less than 0.90 [17]. The sample size for this study was calculated 122 according to the rule required in internal validity studies, which uses the ratio of the number of 123 subjects $(\mathrm{N})$ to the number of items (p) [18].

124 As a second step, a structural equation model with measurement component was estimated to 125 confirm the factor structure obtained through EFA. It was assumed a generalized linear model 126 for ordinal response and link logit. As a final step, in order to take into account that participants

127

128

129

130

131

132

133

134

135

136

137

138

139

140

141

142

143

144

145

146

147

148

149

150

151

152

153

154

155

156

157

158

are nested within two groups $\mathrm{Ob} / \mathrm{Gyn}$ and UAC, a two-levels measurement model was

considered. The LR test, AIC and BIC were used for comparison between the one-level and twolevels SEM models. The Student's t test was used to assess statistical significance of the difference between two women's groups with respect to questionnaire's items and dimensions. A p-value $<0.05$ was chosen for statistical significance. Statistical analysis was conducted using Stata SE/14.2.

\section{RESULTS}

All five experts concurred that the measures should effectively capture any changes in the knowledge about HPV and attitude to vaccination and HPV vaccines, with concern to the first approach to the patient both in hospital and in outpatient service.

Women enrolled at UAC were on average younger $(23.1 \pm 2.45)$ and more educated (100\% high school and more) than women enrolled at Ob/Gyn (35.5 \pm 9.89 years old and 63\% high school and more) (Table 1).

Three dimensions were found trough EFA: "knowledge of HPV infection (kHPV)" (48\% explained variance), correlated with items between Q9 and Q13, "Attitude to get vaccinated against HPV (aHPV)" (26\%), correlated with items Q14-Q15-Q16, and "Knowledge about vaccines (KV)" (23\%), correlated with items from Q1 to Q5. Three items (Q6-Q7, Q8) resulted with high uniqueness $(\geq 0.80)$. Internal consistency was good for the whole questionnaire $(0.82)$ and the first dimension (0.88) and acceptable for the second (0.78) and the third dimension (0.73) (Table 2).

Results of the 1-level measurement SEM model confirmed the three factors structure of the THinK questionnaire (Figure 2). By including the group's level information (Figure 3), the model fit was improved $(\mathrm{p}=0.0223)$.

Of note, $23.1 \%$ of responders showed poor knowledge of HPV and $16.7 \%$ had never heard of it (Q12); For what concerns specific immunization, 21.8\% of patients (Q14) responded that they are very little or not at all available to carry out vaccination. Poor knowledge of HPV induced lesions was expressed by almost half of the women interviewed (44.3\% of women answered no or little at Q11), without any correlation with age or education. About the 19\% of women expressed a clear refusal just to receive even simple information about HPV vaccination (Q16) (data not shown in Tables). 
159 On average, women enrolled at the UAC reported scores significantly higher compared to

160

161

162

163

164

165

166

167

168

169

170

171

172

173

174

175

176

177

178

179

180

181

182

183

184

185

186

187

188

189

190

191

192

193

194

195

196

197

198

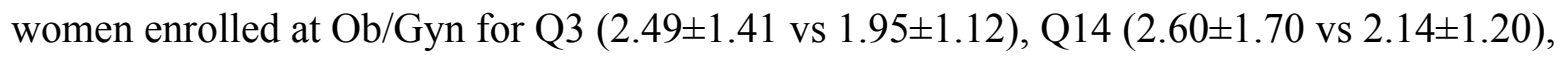
Q15 (2.96 \pm 1.79 vs $2.44 \pm 1.28)$ and aHPV $(0.17 \pm 1.27$ vs $-0.28 \pm 0.93)$. Conversely, their score was significantly lower for Q6 (2.96 \pm 1.41 vs $3.57 \pm 1.14)$ and Q7 (3.15 \pm 1.15 vs $3.68 \pm 1.14)$ (Table 3$)$.

\section{DISCUSSION}

The aim of our study was to perform a reliability and validity study of the proposed THinK questionnaire as well as to assess knowledge of HPV and attitude towards HPV-vaccination in a sample of women living in Palermo.

The THinK questionnaire was found to measure three domains, which we named knowledge of HPV infection, attitude to be vaccinated against HPV and knowledge about vaccines, and it demonstrated adequate internal consistency as a whole and for each one of its three domains. We developed a short and succinct questionnaire with only 16 items in order to get it easier to be used in the first approach to the patient both in hospital and in outpatient service. There are many studies employing questionnaires about HPV issues, but just few use validated questionnaires, and their validity results are in line with those found for the THinK questionnaire. The HAVIQ questionnaire [19], which was designed to evaluate the efficacy of an intervention to affect HPV vaccination knowledge, obtained Cronbach's alpha $>0.6$ for three of its four dimensions. The $25-$ item HPV general knowledge and 11-item HPV vaccination scale, validated on a national sample of Canadian parents of boys, showed internal consistency $>0.70$ [20]. Two questionnaires to measure HPV knowledge on an international sample of adults showed Cronbach's alpha $>0.83$ [21]. Similar reliability was demonstrated for other instruments validated on undergraduates from Pakistan (Cronbach's alpha (0.79) [22] and on adolescents from Greece [23].

The context proposed in our analysis concerns adult females living in Palermo. Rationale for choosing this target was to have indications about women that are yet (or not yet) mothers of girls and boys in vaccination age. Parents' attitude about immunization is extremely important to vaccination of younger girl [24]; disagreement of parents has been the main reason for nonadherence to vaccination of girls aged 11-12 in an Italian Cross sectional study [25].

When analyzing results of our paper, it is necessary to keep in mind that two groups involved in the survey are representative of two different populations. In fact, participants from $\mathrm{Ob} / \mathrm{Gyn}$ are adult women referred for therapeutic purposes while those from the UAC are students or fresh graduates mostly referred for prevention and contraceptive prescription. Results from the 2levels measurement SEM model showed that the group information explains a significant share of the total variability of the responses. This finding strengthens the importance of validating the questionnaire to measure HPV knowledge in specific populations.

One important finding of our study is that more than one in three of women were not conscious about HPV prevention and one in five would be little or no willing to be vaccinated against HPV. Roots of these disappointing results can be explained by a general poor knowledge of HPV [912], lack of information on HPV vaccination given by health professionals to young women [26] 
199

200

201

202

203

204

205

206

207

208

209

210

211

212

213

214

215

216

217

218

219

220

221

222

223

224

225

226

227

228

229

230

231

232

233

234

235

236

237

238

and widespread ignorance about HPV-specific lesions [27], which has been reported also for the Italian general practitioners (GPs) [28]. It's already been suggested that lack of information could represent an important barrier to vaccine acceptation [6]; a cross-sectional pilot study showed higher vaccine-related knowledge in women vaccinated than in non-immunized [29]. Our results are consistent with Censis data, which show that judgment on available information on HPV and vaccinations is not positive, in terms of clarity and quantity [16].

By evaluating answers to the last question, it is possible to hypothesize a strong cultural resistance to vaccination and let us to reflect that a rooted resistance to immunization could play an important role in the HPV vaccine hesitancy [30]. Comparison between response to our questions Q3 and Q4 appears interesting, with 18.6\% of respondents declaring that they were little or not at all favorable to vaccination in adulthood and only $8.6 \%$ being little or nothing convinced of vaccination in pediatric age. The found resistance to vaccination in adulthood, compared to the consolidated acceptance of vaccination in pediatric age, should help to explain the scarce attitude to be vaccinated against HPV in the Ob/Gyn group. Barriers to vaccination in adulthood have been long discussed by several authors and one of the most frequent reasons for failure to immunize is a lack of communication or bad information [31].

Different authors showed the impact of socioeconomic variables on HPV awareness and vaccination: a few reported positive relationship between school education and mother's school level, HPV knowledge and vaccination [32], between age and HPV awareness [33] and between education and the intention to be vaccinated against HPV [34]. Concerning the association with education, findings of our study do not allow to draw definitive conclusions, as it is not possible to distinguish if the major attitude of women enrolled at UAC depends on either the younger age or the higher education of this group compared to $\mathrm{Ob} / \mathrm{Gyn}$.

Through this study, we have provided initial evidence for validation of the THinK questionnaire. There are some margins for improvement of the instrument, as deleting those items resulted with high uniqueness or including additional items to get it more HPV-specific, e.g. concerning sexual behaviors (age at first sexual relationship, number of life partners, partner HPV status), knowledge about HPV induced lesions, smoking cigarettes, alcohol consumption, use of hormonal contraceptives or IUD, personal hygiene, prior infections of the cervico-vaginal tract, parity, HSV. Finally, more research is desirable to examine other aspects as concurrent validity and test-retest reliability with larger sample sizes.

\section{CONCLUSIONS}

The THinK questionnaire demonstrated adequate reliability and validity in a sample of Italian women living in Palermo. This instrument, short and easy to complete and to score, may serve as a useful measure in the primary healthcare setting in order to assess general knowledge about vaccination and HPV vaccines. Even if, in agreement with the guidelines of the Italian Ministry of Health, HPV vaccination is offered free of charge to girls in the twelfth year of life in all 
239 Italian regions since 2007/2008, efforts must be made to create a sound basis for understanding

$240 \mathrm{HPV}$ issues and related risks, with a view to preventing and protecting patients.

\section{REFERENCES}

244 [1] Fang J, Zhang H, Jin S. Epigenetics and cervical cancer: from pathogenesis to therapy.

245 Tumour Biol 2014; 35(6): 5083-93.

246 [2] Clifford GM, Rana RK, Franceschi S. Comparison of HPV type distribution in high-grade 247 cervical lesions and cervical cancer: a meta-analysis. Br J Cancer. 2003;89:101-105.

248 [3] Braaten KP, Laufer MR. Human Papillomavirus (HPV), HPV-Related Disease, and the HPV 249 Vaccine. Rev Obstet Gynecol 2008; 1(1):2-10.

250 [4] Harper DM, DeMars LR. HPV vaccines - A review of the first decade. Gynecol Oncol 2017; 251 146 (1):196-204.

252 [5] Capra G, Giovannelli L, Matranga D, Bellavia C, Guarneri MF, Fasciana T, Scaduto G, 253 Firenze A, Vassiliadis A, Perino A. Potential impact of a nonavalent HPV vaccine on HPV 254 related low-and high-grade cervical intraepithelial lesions: A referral hospital-based study in 255 Sicily. Hum Vacc Immunother 2017; 13(8): 1839-1843.

256 [6] Loke AY, Kwan ML, Wong YT, Wong AKY. The Uptake of Human Papillomavirus 257 Vaccination and Its Associated Factors Among Adolescents: A Systematic Review. J Prim Care 258 Community Health 2017; 8(4):349-362.

259 [7] Ammatuna P, Giovannelli L, Matranga D, Ciriminna S, Perino A. Prevalence of genital 260 human papilloma virus infection and genotypes among young women in Sicily, South Italy. 261 Cancer Epidemiol Biomarkers Prev 2008; 17(8):2002-6.

262 [8] Ministero della Salute. Papillomavirus (Hpv), i dati sulle coperture vaccinali aggiornati al 2632015 ,

264 http://www.salute.gov.it/imgs/C_17_tavole_27_allegati_iitemAllegati_0_fileAllegati_itemFile_0 265 file.pdf; 2015 [accessed 7 March, 2018].

266 [9] Hendry M, Lewis R, Clements A, Damery S, Wilkinson C. "HPV? Never heard of it!" a 267 systematic review of girls' and parents' information needs, views and preferences about human 268 papillomavirus vaccination. Vaccine 2013; 31(45):5152-67.

269 [10] Sopracordevole F, Cigolot F, Gardonio V, Di Giuseppe J, Boselli F, Ciavattini A.

270 Teenagers' knowledge about HPV infection and HPV vaccination in the first year of the public 271 vaccination programme. Eur J Clin Microbiol Infect Dis. 2012 Sep;31(9):2319-25

272 [11] Pelucchi C, Esposito S, Galeone C, Semino M, Sabatini C, Picciolli I, Consolo S, Milani G, 273 Principi N. Knowledge of human papillomavirus infection and its prevention among adolescents 274 and parents in the greater Milan area, Northern Italy. BMC Public Health. 2010 Jun 28;10:378 275 [12] Di Giuseppe G, Abbate R, Liguori G, Albano L, Angelillo IF. Human papillomavirus and 276 vaccination: knowledge, attitudes, and behavioural intention in adolescents and young women in 277 Italy. Br J Cancer 2008; 22;99(2):225-9.

278 [13] Klug SJ, Hukelmann M, Blettner M. Knowledge about infection with human

279 papillomavirus: a systematic review. Prev Med 2008; 46(2):87-98. 
280 [14] Santangelo OE, Provenzano S, Firenze A. Knowledge of sexually transmitted infections and

281

282

283

284

285

286

287

288

289

290

291

292

293

294

295

296

297

298

299

300

301

302

303

304

305

306

307

308

309

310

311

312

313

314

315

316

317

318

319

sex-at-risk among Italian students of health professions. Data from a one-month survey. Ann Ist Super Sanita. 2018 Jan-Mar;54(1):40-48.

[15] Patel H, Jeve YB, Sherman SM, Moss EL. Knowledge of human papillomavirus and the human papillomavirus vaccine in European adolescents: a systematic review. Sex Transm Infect 2016; 92: 474-479.

[16] Censis. CHI HA PAURA DEL PAPILLOMAVIRUS? Com'è cambiato l'atteggiamento dei genitori italiani sulla vaccinazione anti-HPV, 2017;

http://www.quotidianosanita.it/allegati/allegato1837336.pdf [18 April 2018]

[17] Bland J, Altman D. Statistics notes: Cronbach's alpha. BMJ. 1997;314:275.

[18] Rouquette A, Falissard B. Sample size requirements for the internal validation of psychiatric scales Int J Methods Psychiatr Res 2011; 20(4): 235-249

[19] Forster AS, McBride KA, Davies C, Stoney T, Marshall H, McGeechan K, Cooper SC, Skinner SR. Development and validation of measures to evaluate adolescents' knowledge about human papillomavirus (HPV), involvement in HPV vaccine decision-making, self-efficacy to receive the vaccine and fear and anxiety. Public Health 2017; 147:77-83.

[20] Perez S, Tatar O, Ostini R, Shapiro GK, Waller J, Zimet G, Rosberger Z. Extending and validating a human papillomavirus (HPV) knowledge measure in a national sample of Canadian parents of boys. Prev Med 2016; 91: 43-49.

[21] Waller J, Ostini R, Marlow LAV, McCaffery K, Zimet G. Validation of a measure of knowledge about human papillomavirus (HPV) using item response theory and classical test theory. Prev Med 2013; 56: 35-40.

[22] Khan MT, Buksh MA, Rehman IU, Saleem A. Knowledge, attitudes, and perception

towards human papillomavirus among university students in Pakistan. Papillomavirus Res 2016; 2: 122-127.

[23] Anagnostou PA, Aletras VH, Niakas DA. Human papillomavirus knowledge and vaccine acceptability among adolescents in a Greek region. Public Health 2017; 152:145-152.

[24] La Torre G, De Vito E, Ficarra MG, Firenze A, Gregorio P, Miccoli S, Giraldi G, Unim B, De Belvis G, Boccia A, Saulle R; HPV Collaborative Group, Semyonov L, Ferrara M, Langiano E, Capizzi S, Nardella R, Marsala MG, Bonanno V, Ferrara C, Guidi E, Bergamini M, Lupi S. Knowledge, opinions and attitudes of Italian mothers towards HPV vaccination and Pap test. Tumori 2015; 101(3):339-46.

[25] Gualano MR, Stillo M, Mussa MV, Zotti CM. Cross sectional study investigating the differences in knowledge and behaviors about HPV between vaccinated and non-vaccinated girls. J Prev Med Hyg 2016; 57(3): E121-E127.

[26] La Torre G, De Vito E, Ficarra MG, Firenze A, Gregorio P, Boccia A; HPV Collaborative Group. Is there a lack of information on HPV vaccination given by health professionals to young women? Vaccine. 2013 Oct 1;31(42):4710-3

[27] Capogrosso P, Ventimiglia E, Matloob R, Colicchia M, Serino A, Castagna G, Clementi MC, La Croce G, Capitanio U, Gandaglia G, Damiano R, Mirone V, Montorsi F, Salonia A. 
320 Awareness and knowledge of human papillomavirus-related diseases are still dramatically 321 insufficient in the era of high-coverage vaccination programs. World J Urol 2015; 33(6):873-80. 322 [28] Signorelli C, Odone A, Pezzetti F, Spagnoli F, Visciarelli S, Ferrari A, Camia P, Latini C, 323 Ciorba V, Agodi A, Barchitta M, Scotti S, Misericordia P, Pasquarella C. Human Papillomavirus 324 infection and vaccination: knowledge and attitudes of Italian general practitioners. Epidemiol 325 Prev 2014; 38(6 Suppl 2):88-92.

326 [29] Mathur MB, Mathur VS, Reichling DB. Participation in the decision to become vaccinated 327 against human papillomavirus by California high school girls and the predictors of vaccine 328 status. J Pediatr Health Care 2010; 24(1): 14-24.

329 [30] Guzzetta G, Faustini L, Panatto D, Gasparini R, Manfredi P. The impact of HPV female 330 immunization in Italy: model based predictions. PLoS One. 2014 Mar 11;9(3):e91698.

331 [31] Johnson DR, Nichol KL, Lipczynski K, Barriers to adult immunization. Am J Med 2008; 332121 (7 Suppl 2):S28-35.

333 [32] Grandahl M, Larsson M, Dalianis T, Stenhammar C, Tydén T, Westerling R, Nevéus T.

334 Catch-up HPV vaccination status of adolescents in relation to socioeconomic factors, individual 335 beliefs and sexual behaviour. PLoS One 2017;12(11):e0187193.

336 [33] Samkange-Zeeb F, Mikolajczyk RT, Zeeb H. Awareness and knowledge of sexually 337 transmitted diseases among secondary school students in two German cities. J Community 338 Health 2013; 38(2): 293-300.

339 [34] Alberts CJ, van der Loeff MF, Hazeveld Y, de Melker HE, van der Wal MF, Nielen A, El 340 Fakiri F, Prins M, Paulussen TG. A longitudinal study on determinants of HPV vaccination 341 uptake in parents/guardians from different ethnic backgrounds in Amsterdam, the Netherlands.

342 BMC Public Health 2017; 17 (1):220. 


\section{Table $\mathbf{1}$ (on next page)}

Descriptive statistics of 220 Sicilian women by recruitment group

${ }^{\S}$ Student's t-test for quantitative variables, $\mathrm{Chi}^{2}$ or Fisher's exact test for categorical variables 


\begin{tabular}{|l|l|l|l|}
\hline Variables & \multicolumn{1}{|c|}{$\begin{array}{c}\text { University } \\
(\mathrm{N}=136)\end{array}$} & \multicolumn{1}{|c|}{$\begin{array}{c}\text { Outpatient service } \\
(\mathrm{N}=84)\end{array}$} & \multicolumn{1}{c|}{ p-value $^{\S}$} \\
\hline Age (Mean \pm SD) & $35.50 \pm 9.89$ & $23.12 \pm 2.45$ & $<0.001$ \\
\hline Education (n, $\%)$ & & & $<0.001$ \\
\hline No, primary & $1(0.8)$ & $0(0.0)$ & \\
\hline Low Middle School & $49(36.6)$ & $0(0.0)$ & \\
\hline High Middle School & $49(36.6)$ & $70(83.3)$ & \\
\hline Graduate & $35(26.0)$ & $14(16.7)$ & $<0.001$ \\
\hline Citizenship (n,\%) & & & 0.830 \\
\hline Italian & $131(96.3)$ & $80(95.2)$ & \\
\hline European & $2(1.5)$ & $3(3.6)$ & \\
\hline Extra-European & $2(1.5)$ & $1(1.2)$ & \\
\hline n.a. & $1(0.7)$ & - & 0.213 \\
\hline Living place (n, $\%)$ & & & \\
\hline Italy & $134(98.6)$ & $81(96.4)$ & \\
\hline Europe & $1(0.7)$ & $3(3.6)$ & \\
\hline Extra-Europe & - & - & \\
\hline n.a. & $1(0.7)$ & - & \\
\hline
\end{tabular}

1

2 
Table 2 (on next page)

Internal consistency of the THinK questionnaire 


\begin{tabular}{|l|c|}
\hline & $\begin{array}{c}\text { Cronbach's } \\
\text { alpha }\end{array}$ \\
\hline Whole questionnaire & 0.816 \\
\hline kHPV & 0.882 \\
\hline aHPV & 0.784 \\
\hline KV & 0.732 \\
\hline
\end{tabular}

1

2 


\section{Table 3(on next page)}

Knowledge and attitude of 220 Italian women by group: Mean (SD) of responses to THinK questionnaire's items and dimensions 


\begin{tabular}{|c|l|l|l|}
\hline Questionnaire's & \multicolumn{1}{|c|}{$\begin{array}{c}\text { University } \\
(\mathrm{N}=136)\end{array}$} & $\begin{array}{c}\text { Outpatient service } \\
(\mathrm{N}=84)\end{array}$ & \\
\hline Items & & & \\
\hline $\mathrm{Q}_{1}$ & $1.74(1.01)$ & $1.75(0.99)$ & 0.9310 \\
\hline $\mathrm{Q}_{2}$ & $1.55(0.95)$ & $1.83(1.15)$ & 0.0589 \\
\hline $\mathrm{Q}_{3}$ & $1.95(1.12)$ & $2.49(1.41)$ & $\mathbf{0 . 0 0 1 9}$ \\
\hline $\mathrm{Q}_{4}$ & $2.92(1.21)$ & $2.91(1.23)$ & 0.9770 \\
\hline $\mathrm{Q}_{5}$ & $2.58(1.25)$ & $2.24(1.37)$ & 0.0662 \\
\hline $\mathrm{Q}_{6}$ & $3.57(1.14)$ & $2.96(1.41)$ & $\mathbf{0 . 0 0 6 6}$ \\
\hline $\mathrm{Q}_{7}$ & $3.68(1.14)$ & $3.15(1.15)$ & $\mathbf{0 . 0 0 2 9}$ \\
\hline $\mathrm{Q}_{8}$ & $3.58(1.30)$ & $3.93(1.44)$ & 0.0705 \\
\hline $\mathrm{Q}_{9}$ & $2.63(1.32)$ & $2.75(1.47)$ & 0.5195 \\
\hline $\mathrm{Q}_{10}$ & $2.30(1.06)$ & $2.50(1.61)$ & 0.2619 \\
\hline $\mathrm{Q}_{11}$ & $3.06(1.43)$ & $3.09(1.59)$ & 0.8929 \\
\hline $\mathrm{Q}_{12}$ & $2.58(1.42)$ & $2.99(1.64)$ & 0.0597 \\
\hline $\mathrm{Q}_{13}$ & $2.63(1.07)$ & $2.75(1.51)$ & 0.4966 \\
\hline $\mathrm{Q}_{14}$ & $2.14(1.20)$ & $2.60(1.70)$ & $\mathbf{0 . 0 1 9 8}$ \\
\hline $\mathrm{Q}_{15}$ & $2.44(1.28)$ & $2.96(1.79)$ & $\mathbf{0 . 0 1 3 8}$ \\
\hline $\mathrm{Q}_{16}$ & $2.14(1.24)$ & $2.38(1.70)$ & 0.2304 \\
\hline Dimensions & & & 0.9412 \\
\hline $\mathrm{kHPV}$ & $-0.01(0.98)$ & $0.00(1.16)$ & 0.5699 \\
\hline $\mathrm{KV}$ & $-0.06(1.24)$ & $0.04(1.19)$ & $\mathbf{0 . 0 0 2 6}$ \\
\hline $\mathrm{aHPV}$ & $-0.28(0.93)$ & $0.17(1.27)$ & \\
\hline & & & \\
\hline
\end{tabular}




\section{Figure 1 (on next page)}

The 16-items THinK questionnaire 
1. Do you know what vaccines are?

$$
\begin{aligned}
& \square \text { Yes } \\
& \square \text { Much } \\
& \square \text { Somewhat } \\
& \square \text { Little } \\
& \square \text { No }
\end{aligned}
$$

2. Are you favourable with paediatric vaccination?

$$
\begin{aligned}
& \square \text { Yes } \\
& \square \text { Much } \\
& \square \text { Somewhat } \\
& \square \text { Little } \\
& \square \text { No }
\end{aligned}
$$

3. Are you favourable with adults' vaccination?

$$
\begin{aligned}
& \square \text { Yes } \\
& \square \text { Much } \\
& \square \text { Somewhat } \\
& \square \text { Little } \\
& \square \text { No }
\end{aligned}
$$

4. Do you know what vaccines are available today for the Italian population?

$$
\begin{aligned}
& \square \text { Yes } \\
& \square \text { Much } \\
& \square \text { Somewhat } \\
& \square \text { Little } \\
& \square \text { No }
\end{aligned}
$$

5. Do you know by who and where could you be vaccinated?

$$
\begin{aligned}
& \square \text { Yes } \\
& \square \text { Much } \\
& \square \text { Somewhat } \\
& \square \text { Little } \\
& \square \text { No }
\end{aligned}
$$

6. Do you think that vaccines have any side effects?

$$
\begin{aligned}
& \square \text { Yes } \\
& \square \text { Much }
\end{aligned}
$$

$$
\begin{aligned}
& \square \text { Somewhat } \\
& \square \text { Little } \\
& \square \text { No }
\end{aligned}
$$

7. Can you contract a disease even if you are vaccinated against it?

$$
\begin{aligned}
& \square \text { Yes } \\
& \square \text { Much } \\
& \square \text { Somewhat } \\
& \square \text { Little } \\
& \square \text { No }
\end{aligned}
$$

8. Do you think that vaccination is effective even after contracting infection or having been in contact with a contagious case?

$\square$ Yes

$\square$ Much

$\square$ Somewhat

$\square$ Little

$\square$ No

9. Do you know what HPV is?

$$
\begin{aligned}
& \square \text { Yes } \\
& \square \text { Much } \\
& \square \text { Somewhat } \\
& \square \text { Little } \\
& \square \text { No }
\end{aligned}
$$

10. Do you think that HPV is dangerous?

$$
\begin{aligned}
& \square \text { Yes } \\
& \square \text { Much } \\
& \square \text { Somewhat } \\
& \square \text { Little } \\
& \square \text { No }
\end{aligned}
$$

11. Do you know lesions related to HPV infection?

$$
\begin{aligned}
& \square \text { Yes } \\
& \square \text { Much } \\
& \square \text { Somewhat } \\
& \square \text { Little } \\
& \square \text { No }
\end{aligned}
$$

12. Have you ever heard about vaccination and prevention against HPV?

$$
\begin{aligned}
& \square \text { Yes } \\
& \square \text { Much } \\
& \square \text { Somewhat } \\
& \square \text { Little } \\
& \square \text { No }
\end{aligned}
$$

13. Do you think that is high the probability of contracting HPV infection?

$$
\begin{aligned}
& \square \text { Yes } \\
& \square \text { Much } \\
& \square \text { Somewhat } \\
& \square \text { Little } \\
& \square \text { No }
\end{aligned}
$$

14. Would you be willing to get vaccinated against HPV?

$$
\begin{aligned}
& \square \text { Yes } \\
& \square \text { Much } \\
& \square \text { Somewhat } \\
& \square \text { Little } \\
& \square \text { No }
\end{aligned}
$$

15. Do you consider useful asking to your partner to get vaccinated against HPV?

$$
\begin{aligned}
& \square \text { Yes } \\
& \square \text { Much } \\
& \square \text { Somewhat } \\
& \square \text { Little } \\
& \square \text { No }
\end{aligned}
$$

16. Do you want to receive information about HPV vaccination?

$$
\begin{aligned}
& \square \text { Yes } \\
& \square \text { Much } \\
& \square \text { Somewhat } \\
& \square \text { Little } \\
& \square \text { No }
\end{aligned}
$$


Figure 2

Construct validity of the HPV Questionnaire in a sample of Sicilian adult women: paths obtained from 1-level measurement SEM model

kHPV = "knowledge of HPV infection", KV="Knowledge about vaccines", aHPV="Attitude to get vaccinated against HPV",Q1-Q16=Questionnaire's items

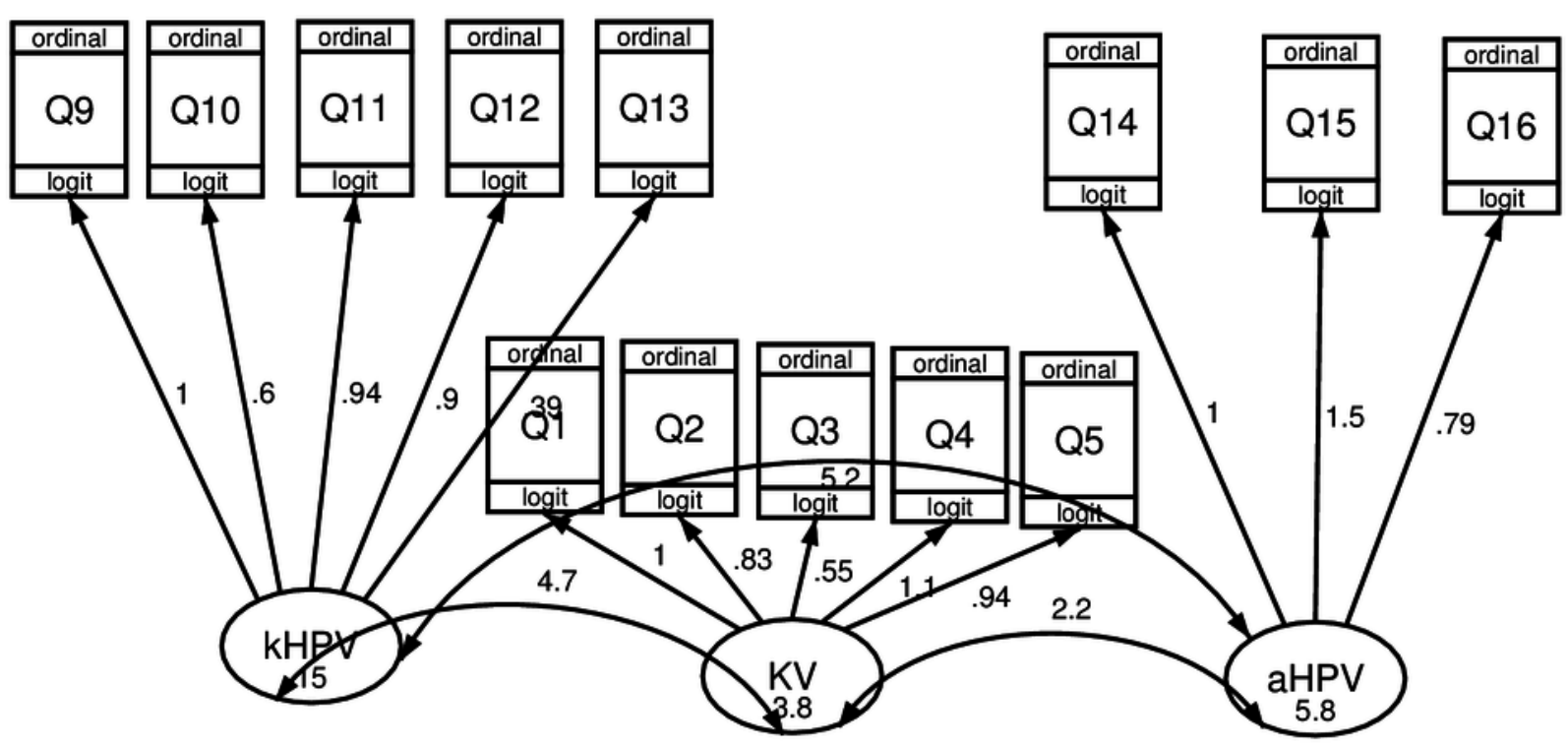


Figure 3

Construct validity of the HPV Questionnaire in a sample of Sicilian adult women: paths obtained from two-levels measurement SEM model

kHPV = "knowledge of HPV infection", KV="Knowledge about vaccines", aHPV="Attitude to get vaccinated against HPV",Q1-Q16=Questionnaire's items

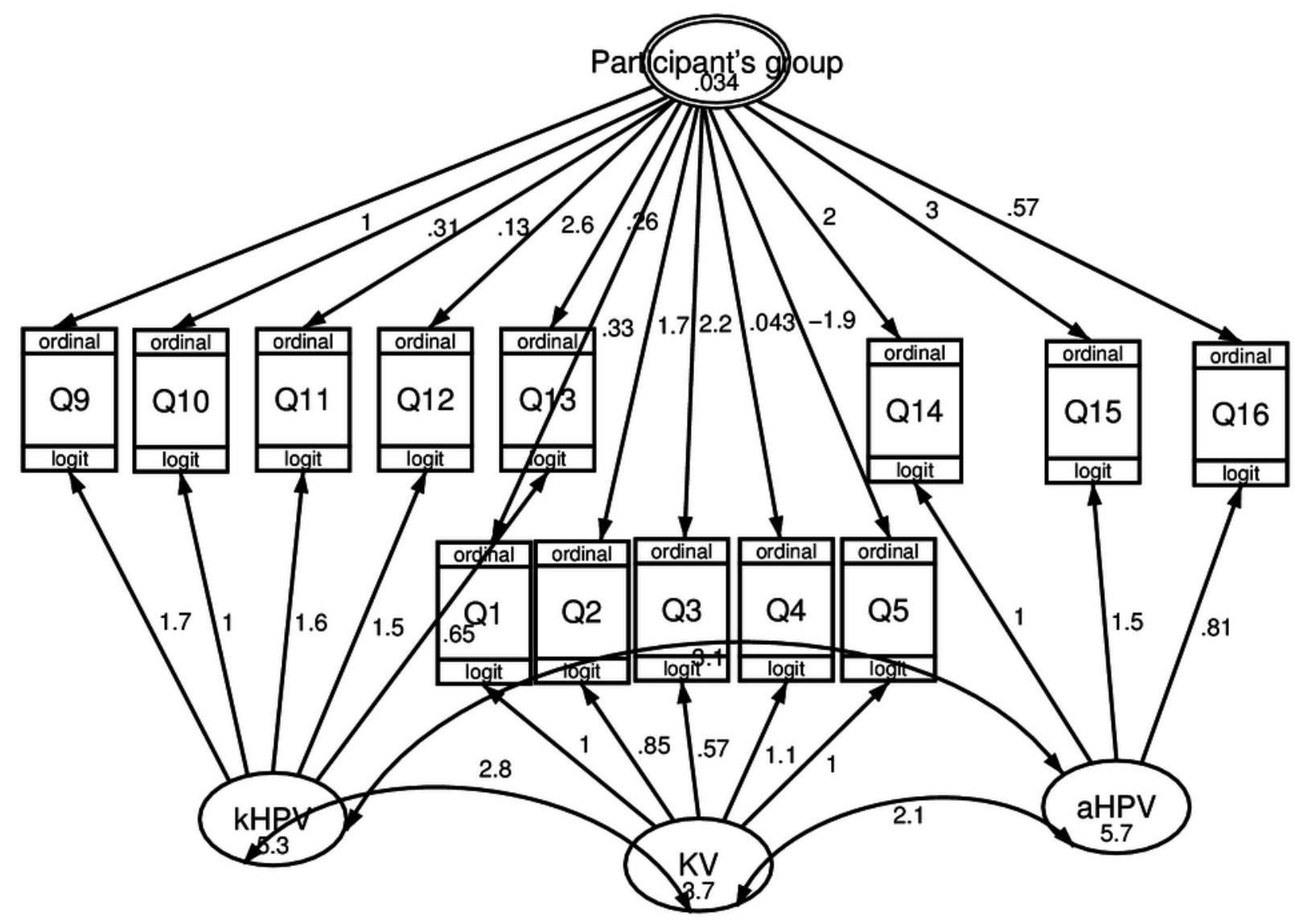

